\title{
REEGLID JA ANALOOGIA VÕÕRKEELEÕPPES SOOME MITMUSEVORMIDE KÄÄNAMISE NÄITEL
}

\section{Annekatrin Kaivapalu}

Ülevaade. Võõrkeeleõppe teooria ja praktika keskseid küsimusi on reeglite ja analoogia ülesannete ning efektiivsuse määratlemine sõnamuutmisprotsessis. Varasemate uurimistulemuste põhjal on sobivaimaks osutunud lähenemisviis, mille põhjal reegleid ja analoogiat ei käsitata vastanditena, vaid ühtse nähtuse eri pooltena, sama kontiinumi äärealadena. Reeglite kasutamine on tõhusam olukorras, kus ei esine erandeid ja sõnamuutmine on algoritmiliselt kergesti kirjeldatav. Kui käänamise või pööramise kirjeldamine on keeruline, annab paremaid tulemusi mallsõna analoogia. Kontiinumis on ka mitmeid vahealasid, millest osa on tingitud õppijate lähtekeelest. Kui lähtekeel ja sihtkeel on tüpoloogiliselt sarnased sugulaskeeled, kasutatakse lisaks sihtkeele reeglitele ja analoogiale veel lähtekeele analoogiat ning lähte- ja sihtkeele koodide seostamist. Käesolevas artiklis käsitletakse eesti ja vene õpilaste reegli- ja analoogiakasutust soome mitmusevormide käänamisel. Analüüs põhineb kirjalikel ja suulistel üksiksõnatestidel, testisõnade käänamisel kirjalikes jutustustes ning õpilaste kommentaaridel oma tegevuse kohta. Eesmärk on välja selgitada, kas ja millises ulatuses mõjutab lähtekeel ja sihtkeele oskamise tase õppijate strateegiavalikut.

Võtmesõnad: võõrkeele omandamine, eesti ja vene õppijad, keeletestid, morfoloogilised oskused, käänamisstrateegiad, lähtekeele mõju, soome keel 


\section{Reeglid ja analoogia kui kesksed sõnamuutmisstrateegiad}

Reeglite ja analoogia paremus keelenähtuste seletajana, nende omavaheline suhe, ülesanded ja jaotumine on olnud väitlusobjektiks mitmes keeleteaduse valdkonnas (nt Anttila 1989, Hint 1998: 233-247, Itkonen 1992, 2005, Muuk 1925. Järsk piiritõmbamine kahe keskse protsessi vahele on siiski osutunud kõikjal keeruliseks ja tarbetukski ning vastandamise asemel rõhutatakse üha enam reeglite ja analoogia ühtsust. Reegleid ja analoogiat ei käsitata niisiis vastanditena, vaid pigem sama ilmingu eri külgedena, kontiinumi äärealadena, mille kõrval on palju vahevariante ja mis lähevad seetõttu sujuvalt teineteiseks üle (Itkonen 1976, Kasik 1995).

Reeglite ja analoogia kasutamistingimuste ning efektiivsuse määratlemine on võõrkeeleõppe olulisemaid küsimusi. Reeglite all mõistetakse võõrkeeleõppes tavaliselt teatud tingimustes samamoodi korduvat protsessi, mida võib kirjeldada, defineerides selle tingimused, piirangud ja protsessi kulu. Reegli esitamisviis on siinjuures teisejärguline. Ulatuslikult muutemorfoloogiat kasutavates keeltes, nagu eesti ja soome keel, on sobivaima strateegia leidmine eriti oluline morfoloogiliste vormide moodustamisel. Morfoloogiaõppes määratletakse reeglid kui protsessid, mille abil põhivormist moodustatakse teisi sõnavorme. Sõnamuutmisel on reeglite kasutamine osutunud tõhusamaks juhul, kui muutmisprotsess on kergesti kirjeldatav ja erandeid ei esine. Kui sõnamuutmist kirjeldada on keeruline, annab paremaid tulemusi analoogia - loov protsess, mis põhineb võrreldavate vormide tegelikul või oletataval sarnasusel. Analoogia puhul kasutatakse malle ehk tüüpsõnu, mille eeskujust sõnamuutmisel lähtutakse (Martin 1995: 201, 264-265; 1999).

Psühholingvistika seisukohalt on sõnamuutmisstrateegia valik seotud sõna muutevormide esinemisega mälus ning õppija võimega mälus esinevat keeleainest kasutada. On vähemalt neli teoreetilist võimalust (Martin 1996: 188-190, Järvikivi 2003: 5-16).

1. Kõik sõnavormid esinevad mälus valmiskujul ja need otsitakse vormi moodustamisel mälust üles mingisuguse süsteemi abil. See võimalus (vähemalt ainsa variandina) ei ole tõenäoline seetõttu, et tavaliselt muudavad emakeele kõnelejad tehissõnu üsna üksmeelselt, kuigi neid ei ole olnud võimalik eelnevalt mällu talletada.

2. Mälus on sõna põhivorm, millest muud sõnavormid moodustatakse teatud reeglite abil. Reeglite süsteem sisaldab tüvemoodustusreegleid koos fonoloogiliste ja leksikaalsete piirangutega. See võimalus on põhimõtteliselt võimalik ulatusliku muutemorfoloogiaga keelte, nagu eesti ja soome, puhul. Sellele tugineb traditsiooniline eesti ja soome keele õpetus võõrkeelena, samuti võrdlev ja vigade analüüsist lähtuv keeleuurimine.

3. Sõnavormid moodustatakse õpitud mallsõnade eeskujul. Tundmatute sõnade tarvis leitakse mingis mõttes sarnane eeskujusõna, millele toetudes sõna muudetakse. Sõnad esinevad mälus võrgustikuna, mis sisaldab nii paradigmaatilisi kui ka lekseemidevahelisi seoseid (Paunonen 1983, Bybee 1988, 2001).

4. Sõnavormid esinevad mälus tüve-, tunnuse- ja lõpuallomorfidena, mis ühendatakse vormimoodustusprotsessis (Niemi jt 1994). Järelikult peab 
kaasnema ka teave selle kohta, milliste tüveallomorfidega neid võib ühendada.

On mõistagi võimalik ja isegi tõenäoline (Martin 1995: 199), et ka ühes keeles kasutatakse kõiki või vähemalt mitut mehhanismi: eri sõnarühmad moodustatakse erinevalt, igal üksikjuhul sobivaimat strateegiat rakendades. Brian MacWhinney (1987) Competition Model'i põhjal kasutatakse morfoloogiliste vormide puhul mehhaanilist moodustamist (by rote), ühendamist (by rule) ja analoogiat (by analogy). Mehhaanilisest moodustamisest võib rääkida siis, kui õppija kasutab õigesti tuntud sõnavorme, kuid ei oska käänata või pöörata tundmatuid sõnu, ka mitte toetavas lause- ja morfoloogilises kontekstis. Ühendamise puhul moodustab õppija valesti ebareeglipärased, kuid õigesti tähenduseta reeglipärased sõnavormid. Kui õppija valib vormi keelevaatluse (võrdluse) alusel, on tegemist analoogiaga.

Keeleõpet ja -kasutust käsitab B. MacWhinney (1987) astmestikuna mehhaanilisest moodustamisest analoogiani, kontiinumina, kus igal mehhanismil on oma ülesanne. B. MacWhinney järgi üritab õppija kõigepealt soovitut väljendada mehhaaniliselt, mällu (leksikasse) talletatud sõnavormi abil. Kui see ebaõnnestub, proovib ta tüve-, tunnuse- ja lõpuallomorfide ühendamist. (Ka B. MacWhinney pooldab oletust, et keeleaines on mälus talletatud tüve-, tunnuse- ja lõpuallomorfidena.) Kui see ebaõnnestub, siirdutakse analoogia juurde: õppija võrdleb tulemust oma teadmistega õpitavast keelest või väljastpoolt, näiteks õpetajalt või kaasvestlejalt saadud tagasisidega (esimesel juhul on tegemist sisemise, teisel juhul välise monitooringuga). Ühendamise teel saadud väär vorm asendatakse analoogia abil moodustatud vormiga. Lihtsamalt öeldes: keeleõppija proovib kõigepealt kasutada reegleid, siis alles analoogiat.

\section{Lähtekeele mõju sõnamuutmisstrateegia valikule}

Lähtekeele mõjust sihtkeeleõppele on aja jooksul esitatud vastandlikke arvamusi (vt nt Ringbom 1987, Odlin 1989, Latomaa 1993, Sajavaara 1999a, 1999b). Siiski on teise keele ja võõrkeele õppe uurijad praegu üsna üksmeelselt seisukohal, et õppijakeelt mõjutavad muuhulgas erinevad lähte- ja sihtkeele vahelised suhted. Eri arvamusel ollakse aga selles osas, kuidas, kuivõrd ja millisel õppimise etapil lähtekeel sihtkeele õpet mõjutab ning millised sihtkeele valdkonnad on lähtekeele mõjule altimad (Schmidt 2001).

Tüpoloogiliselt ja geneetiliselt lähedased keeled on teise keele ja võõrkeele õppimisel tavalisest erinevas olukorras. Uurijad (nt Sajavaara 1994, 1999b: 123, Jarvis, Odlin 2000) on arvamusel, et sihtkeelele lähedase lähtekeele grammatilisest kompetentsist on õppijal abi: lähtekeele mallile toetumine võib viia soovitava tulemuseni ka sihtkeeles. Niisiis, mida lähedasemad on lähte- ja sihtkeel, seda kiiremini sihtkeelt õpitakse, eriti õppimise algperioodil. Sihtkeele õppimise keerulisus ei ole siiski üheselt tingitud lähte- ja sihtkeele vahelisest suurest tüpoloogilisest erinevusest. Õppija jaoks võivad olla problemaatilised ka väikesed erinevused lähtekeelele lähedases sihtkeeles. Samuti ei tarvitse keelesüsteemide võrdlusest lähtuv tüpoloogiline sarnasus ning erinevus langeda kokku keeleõppija arusaamisega lähte- ja sihtkeele sarnasusest ning erinevusest. Võõrkeele õppimisel 
võib viimane osutuda otsustavaks, sest keeltevaheline tüpoloogiline sarnasus või erinevus realiseerub keeleõppija kaudu, realiseerub õppija arusaamisena ja tähelepanekutena õpitavast keelest (Sajavaara 1994: 22).

Vaagides keeleainese mälus talletamise teoreetilisi võimalusi enam kui ühe keele puhul, tulevad kõne alla järgmised variandid (Martin 2006).

1. Iga keele jaoks on oma moodustamismehhanism. See lähenemisviis kehtib ühe keele kirjeldamisel, kuid põhjustab raskusi, kui analüüsitakse kakskeelset või sihtkeele kasutust. Õppija peaks siis ära õppima mitte üksnes teise keele elemendid ja reeglid, vaid täiesti uue mehhanismi. Teine võimalus on kasutada lähtekeele mehhanismi ka sihtkeeles: sel juhul võib tulemus pealtnäha paista sama mis emakeelsel kõnelejal, kuid moodustamise seisukohalt on see hoopis teine. Seda võimalust on kirjeldatud üksnes teoreetiliselt (Hankammer 1992: 405, Martin 1999 järgi), ilma toetava empiirilise materjalita. Ebatõenäolisusele vaatamata seletaks see asjaolu, et lähedast sugulaskeelt õpitakse kergemini ja kiiremini kui tüpoloogiliselt erinevat keelt: lähisugukeelte mehhanismid on samad. Mõistagi on ka muid võimalikke seletusi.

2. Kõikide keelte jaoks on üks universaalne moodustamismehhanism. Sellisel juhul tuleb ära õppida vaid sihtkeele sõnad ja struktuur, mitte mehhanism. Näiteks kui oletatakse, et keelevorme moodustatakse reeglite abil, tuleks sihtkeelt õppides omandada vaid põhivormid ja reeglistik. Kui usutakse, et keel toimib analoogia põhjal, kehtiks see kõikide keelte kohta. Sellel arusaamal põhinevad morfoloogia kirjeldusmallid IA (Item and Arrangement), IP (Item and Process) ja WP (Word and Paradigm) (Hockett 1954). Selle lähtekoha nõrgaks küljeks peetakse ebaökonoomsust: ei ole otstarbekas raisata mälumahtu siis, kui lihtsa protsessi abil on võimalik moodustada suurt hulka vorme, mitte kasutada reegleid, mis kehtivad vaid üksikjuhtude kohta.

3. Eri keeltes on mitmeid keelespetsifilisi moodustamismehhanisme. Kui oletatakse, et kõigil inimestel on võime kasutada mitmeid mehhanisme, võib nende keelespetsiifilisus avalduda kaheti. Kitsam käsitus oleks, et üks keel kasutab üht mehhanismi üheks ja teist teiseks vajaduseks ning teisel keelel oleksid hoopis erinevad mehhanismid. Sellisel juhul nõuaks keele õppimine vaid mehhanismide õppimist. Avarama arusaama korral oletatakse, et kõikides keeltes on mitmeid mehhanisme, osalt samu, osalt erinevaid ning ka nende jaotumine on erinev.

4. Kõikides keeltes on mitmeid universaalseid keelemoodustamismehhanisme. Mehhanismide paljusus võib universaalne olla kahel viisil. Kategoorilisem väide on, et kõik universaalsed mehhanismid on kõikide kasutuses ja neid rakendatakse ühepalju. Vähem kategoorilise väite järgi on võimalik, et kõik universaalsed mehhanismid on kõikide kasutuses, kuid kasutamise jaotus sõltub keelest. Viimasest lähtutakse ka Competition Model'is (MacWhinney 1987).

Käesolev analüüs põhineb viimati mainitud seisukohal, et on mitmeid universaalseid moodustamismehhanisme, kuid nende kasutus ja jaotumine on keeliti erinev. Eeldatakse ka, et sihtkeele sõnamuutmisstrateegia valikut mõjutab muu- 
hulgas õpetamisviis, mis osaliselt sõltub lähtekeelsest õpetamistraditsioonist ning -kultuurist laiemaltki.

\section{Soome keele õpetamine võõrkeelena}

Soome keele õpetamine võõrkeelena, eriti morfoloogiaõpetus, on Eestis traditsiooniliselt olnud reeglikeskne. Reeglitele tugineb morfoloogia õpetamine ka eesti üldhariduskoolides enim kasutatavas õpikus "Yy kaa koo" (Sark 1994, 1995). Õppijale näidatakse, et sõnal võib olla mitmeid tüveallomorfe, mis reeglite abil saadakse soome noomeni põhivormist, ainsuse nominatiivist (Sark 1994: 19, 24). Siiski lähenetakse selles õpikus morfoloogiaõpetusele astmeliselt (nagu Competition Model'is, MacWhinney 1987): kui õppijad on harjunud teadmisega, et sõnal on mitmeid tüve-, tunnuse- ja lõpuallomorfe, saab neid hakata ühendama (Sark 1994: 23). Noomeni mitmusevormide õpetamisel järgitakse just seda põhimõtet (Sark 1995: 35-38). Analoogiat hakatakse rakendama alles siis, kui õppijad on teadlikud erinevatest tüve- ja sufiksiallomorfide kombinatsioonidest, mille vahel on võimalik valida (Sark 1995: 41-43). Huvitaval kombel kaldutakse astmelisusest kõrvale pikemate kui kahesilbiliste noomenite mitmuse partitiivi õpetamisel (Sark 1995: 38-39): keerulise hierarhilise reeglistiku asemel esitatakse kohe valmiskujul mitmuse partitiivi mallid. Niisiis lähtutakse muutemorfoloogia õpetamisel tõenäoliselt kogemuse põhjal reeglite ja analoogia vahelisest tööjaotusest: reegleid kasutatakse eranditeta juhtumite õpetamisel ja analoogiat siis, kui reeglite rakendamine osutub õppija jaoks keeruliseks.

Venemaa Föderatsiooni koolides on käibel peamiselt õpetajate koostatud õppevara, mille sisu ja materjali esitamise metoodika vahelduvad suuresti (Milovidova 1999a, 1999b, 1999c). Soome muutemorfoloogia õpetamisel käesoleva uurimuse venekeelsetele sihtrühmadele on lähtutud esmajoones sõna lõpphäälikutest, Competition Model'i terminoloogiat kasutades morfofonoloogilisest vihjest. Nagu selgub alljärgnevast õpetaja (N.M.) ja õpilase (M.) dialoogist, paigutatakse käänatav sõna lõpphäälikute analoogia põhjal teatud muuttüüpi ja seejärel hakatakse rakendama reegleid. Samal ajal rõhutatakse sõnavormide vahelisi ehk paradigmasiseseid seoseid.

M.: toinen : toi-

N.M.: На что ты думаешь?

М.: На окончание.

N.M.: Вот это важно очень. Что ты думаешь? Главное, -nеп меняется на $-s e$.

M.: $-k s e$

N.M.: -se

M.: $-k s$ : $-k s i a:-k s i a$

N.M.: Не-ksi, где здесь -kse? -nen на -se. В принципе, видите, мы их так и научим. Посмотрит только на конец слова, потому что иначе это не даже по примеру всегда выходит, а конец слова ..

M.: toi- : toi- : toisia : toisiin : toi/si- : toi/sis/ta это другой и второй nirkas : nirka/ksia 
N.M.: Смотри внимательно, на что слово заканчивается? На -as, это значит, что в конце две - $a$, правда?

M.: nirk/ka/sia

N.M.: Так, nirkkaita

M.: nirk/kai/ta : nirk/kai/hin

N.M.: Если -ta, значит...

M.: -siin nirk/kai/siin : nirk/kais/ta, hidas : hida/ksia

N.M.: hidas. Какое слова надо вспомнить?

M.: Ox, на -as

N.M.: Это значит, что hidas : hitaa- : hitai/ta

M.: hitaita : hitai/siin : hitaisi/sta : hitai- hitaista

Analoogia esineb siin mitteklassikalisel kujul - reeglite rakendamise eeldusena ning seob omal kombel käänamisreeglid paradigmadega. Igapäevases õppetöös teatakse siis kogemuste põhjal, et sõnamuutmissüsteem ei ole ühtlane ja selle kõiki osi ei saa kirjeldada ja õpetada ühtmoodi. Eri tüüpi sõnamuutmisnähtusi tuleb õpetada erinevalt, kasutades seejuures maksimaalselt ära kõiki võimalikke strateegiaid, sest nii õppimis- kui moodustamisprotsess on heterogeensed ja dünaamilised.

\section{Informandid ja ainestik}

Käesolevas artiklis otsitakse vastust küsimusele, kuidas mõjutavad õppijate lähtekeel ja sihtkeele oskamise tase käänamisstrateegia valikut, milliseid strateegiaid kasutavad eesti ja vene õppijad soome noomeni käänamisel mitmuses ning millised on eri käänamisstrateegiate ülesanded ja jaotumine.

Uurimuse eestikeelsed sihtrühmad erinevad teineteisest oluliselt õppimisaja pikkuse suhtes. Hiiumaa Kärdla Keskkooli (praeguse Kärdla Ühisgümnaasiumi) ja Tartu Forseliuse Gümnaasiumi 20 abiturienti alustasid soome keele õpinguid 10. klassis C-keele ehk kolmanda võõrkeelena Kaare Sargi õpiku "Yy kaa koo" (1994, 1995) järgi. Kuivõrd enamikus Eesti koolides õpitakse soome keelt C-keelena (Lipasti 2005), on tegemist n-ö prototüüprühmaga. Käesolevas artiklis on C-keele õppijate kohta kasutatud kokkuleppelist nimetust "algajad", kuigi ainestiku kogumise ajaks olid nad õppinud soome keelt umbes 200 tundi.

Kärdla Keskkooli teine informantide rühm, kokkuleppelise nimetusega "edasijõudnud”, on soome keele õppimise seisukohalt Eesti koolisüsteemis erandlik. Edasijõudnud alustasid soome keele õppimist valikainena 6. klassis Taimi Mäntylä õpikute "Aloitamme yhdessä" (1993), “Jatkamme yhdessä” (1994) ja “Juhlimme yhdessä" (1996) põhjal. Gümnaasiumiastmes jätkati õpinguid Klarika Sanderi ja Aira Parviaise sugestiivõppe elemente sisaldava õpiku "Löytöretki Suomeen" (1998) järgi. Soome noomenite käänamist mitmuses õpetati siiski edasijõudnutelegi Kaare Sargi "Yy kaa koo" abil. Viimase kooliaasta kevadeks oli edasijõudnute rühm õppinud soome keelt võõrkeelena umbes 450 tundi ehk üle kahe korra rohkem kui algajad. Õppimisaja pikkus kajastub eeldatavasti ka sihtkeele oskamise tasemes: on loomulik, et kauem õppinud oskavad seda paremini. Kõik eesti informandid olid õppinud esimese võõrkeelena inglise keelt (alates 3. klassist) ja 
teise võõrkeelena vene või saksa keelt (6. klassist) ehk neil oli varasem kogemus kahe indoeuroopa keele õppimisest võõrkeelena.

Ka vene sihtrühmad (mõlemad Peterburi koolist nr 204) erinevad teineteisest soome keele õppimisaja pikkuse suhtes. Kool on spetsialiseerunud soome keele õpetamisele (eri aegadel eri mahus ja eri õppekavade järgi). Õppevara on samuti palju vaheldunud: lisaks finska- ja soome keele kui teise keele õppematerjalidele on õpetatud mitmete oma kooli õpetajate koostatud materjalide põhjal (Milovidova 1999a: 73, 1999b: 292, 1999c: 64.) Venekeelsed edasijõudnud olid õppinud soome keelt alates 1. klassist ning 9. klassi sügiseks läbinud umbes 550-tunnise kursuse. Venekeelsed algajad olid alustanud gümnaasiumiastmes ning ainestiku kogumise ajaks abituuriumikevadel õppinud soome keelt umbes 200 tundi. Lisaks emakeelele ning soome keelele olid vene informandid oppinud inglise ja rootsi keelt.

Eesti- ja venekeelsed sihtrühmad on siis nii soome keele õppimisaja pikkuse kui ka võõrkeelte õppimise kogemuse poolest hästi võrreldavad. Eesti ja vene edasijõudnute paariaastane vanusevahe ei takista tulemuste võrdlemist ja tõlgendamist, sest kognitiivse arengu seisukohalt on mõlemal juhul tegemist noorte täiskasvanutega (Jaakkola 1997: 68).

Uurimisainestik on kogutud 2001-2003 (Kärdlas, Tartus ja Peterburis) eri meetoditel: kirjalikud ja suulised üksiksõnatestid, kirjalikud jutustused (vt lisa 1), lindistatud on õppijate kommentaare oma käänamisprotsessi kohta testi sooritamise ajal ning tehtud retrospektiivseid intervjuusid õppijatega nende emakeeles. ${ }^{1}$ Kahe viimati nimetatud meetodi kombinatsiooni on peetud parimaks, kuigi mitte täiuslikuks võimaluseks saada informatsiooni mentaalsetest protsessidest (Block 1992, Swain, Lapkin 1995). Eriti informatiivseks osutusid õppijate kommentaarid oma tegevuse kohta, mida vajadusel intervjuudes täpsustati. Varasemateski uurimustes (nt Martin 1995: 267) on tõdetud, et õppijad on üldiselt teadlikud oma tegevusest sõnavormide moodustamise ajal ja on võimelised seda kirjeldama, kuigi üldistest õppimisstrateegiatest rääkimine on kergem ja õppijate kirjeldamisoskus võib olla erinev.

Mitmeid vihjeid käänamisstrateegiate valikust ja rakendamisest andis suuline üksiksõnatest: käändevormi moodustamisel esinenud pausid, kordused ja parandused viitasid sageli kasutatud moodustamismehhanismile. Nii kirjalikus kui ka suulises üksiksõnatestis esinevate tehissõnade käänamise eesmärgiks oli selgitada, kuidas toimib keeleõppija nende sõnade moodustamisel, mida kindlasti ei ole tema mällu talletatud. Käänamistesti tehissõnad nirkas, syhmä, sulkki ja veule moodustati sõnadest kirkas, tyhmä, tulkki ja neule algustähe asendamise teel.

Käänamisprotsessile heidavad valgust ka õppijate vead ja parandused kirjalikus üksiksõnatestis ning jutustustes. Vigu on tavaliselt defineeritud kui tahtmatuid kõrvalekaldeid normist. Tehnilisem määratlus on esitatud konnektsionismi kontekstis: näiteks U. Schade ja U. Laubenstein (1993: 86, Hokkanen 2001 järgi) väidavad, et "vigu esineb siis, kui sihtnärviraku aktiveerimine on väiksem kui peaks, mistõttu valitakse mõni muu element." Viimase aastakümne jooksul on psühholingvistikas hakatud rääkima vigadest kui olulistest mentaalsete protsesside välistest peegeldajatest (Hokkanen 2001: 13-14). Keele moodustamisprotsessi on veatu vormi puhul raske jälgida, viga aga võib paljastada oma allika.

${ }^{1}$ Käänamistesti koostamise ja testisõnade valiku kohta üksikasjalikumalt vt Kaivapalu 2005, 2006. 
Õppijate vead on seega tähtis uurimisainestik, aken protsessi. Samas võib teatud tingimustes ka suur õigete vastuste protsent vihjata käänamisstrateegia valikule.

Siinses töös üritatakse käänamisprotsessile läheneda eeskätt õppijate moodustatud sõnavormide kaudu.

\section{Eesti ja vene õpilaste strateegiad soome mitmusevormide käänamisel}

Enam levinud käänamisstrateegiana mainitakse tavaliselt reeglite ja analoogia kasutamist ning sõnavormide moodustamist mälu järgi (Martin 1995: 267). Piiritõmbamine reeglite järgimise ja allomorfide ühendamise vahele ei ole alati lihtne. Kahtluseta võib ühendamiseks pidada vaid n-ö aglutinatiivseid vigu, milles muuteallomorf on otse liidetud noomeni põhivormi, soome keeles ainsuse nominatiivi, tüvele. Aglutinatiivseid vigu esineb nii eesti kui ka vene õppijate testivastuste hulgas:

(1) vierasja, tuoteja, tuotehin, hernehin, hernesïn, patsashin

Reeglipõhine moodustamine on tõenäoline siis, kui käänamisel kasutatakse sihtkeeles olematuid tüveallomorfe (Hokkanen 2001: 103-104). Reeglite rakendamisele viitab õppijate moodustatud käändevormides näiteks tüvevokaali muutus mitmuse tunnuse ees juhul, kui vokaalivaheldust normikohaselt ei esine:

(2) tuotija, vilkkeja, talvirenkoja, kangoihin, lainista

Ilmselt ei seostu õppijate keeletajus sõnavormi mitmuslikkusega mitte üksnes mitmuse tunnuse väljendatud grammatiline tähendus, vaid lisaks sellele vokaali muutumine mitmuse tunnuse ees. Eesti õppijate sellist arusaama toetab tõenäoliselt emakeele tüvemitmus, kuid samasuguseid normivastaseid vokaalivaheldusi esineb ka venekeelsete õppijate testivastustes. Õppijad kalduvad niisiis alateadlikult tugevdama sõnavormi mitmuslikkust vokaalivahelduse abil. Seejuures ei ole õppijale tähtis, millised vokaalid vahelduvad, oluline on muutus kui selline. Vaid $i$-tüvelistes sõnades välditakse tüvevokaali muutmist, ilmselt seetõttu, et $-i$ juba näib olevat mitmuse tunnus.

Huvitaval kombel järgivad õppijad sellises olukorras sihtkeele morfofonoloogilisi reegleid. Nii eesti kui ka vene õppijate soosituim tüvevokaal mitmuse tunnuse ees on - $o$, mis normikohaselt on mitmuse tüvevokaaliks vaid $a$-tüvelistes sõnades. Tänapäeva soome keeles on vaheldus a > o "tavaolukorras ilmselgelt produktiivne" (Niemi jt 2001: 191). Õppijate testivastustes laieneb see produktiivne vaheldus ka teiste muuttüüpide sõnadesse juhul, kui takistamas ei ole soome keeles kahesilbilistes $a$-tüvelistes sõnades esinevat dissimilatoorset tendentsi (Remes 1995: 83). Mainitud tendents avaldub sõna esimese silbi vokaali mõjus tüvevokaalile: esimese silbi vokaali labiaalsus takistab tüvevokaali labialiseerumist ja vastavalt esimese silbi vokaali illaabiaalsus säilitab tüvevokaali labiaalsena. Niisiis võib siinse ainestiku põhjal tõdeda, et õppijakeeleski alluvad grammatikareeglid häälikusüsteemi reeglitele (Hint 1998: 229) ja sihtkeele süsteemi loomisel toimivad selles valitsevad seaduspärasused (Paunonen 1983: 71). 
Sihtkeeles tegelikult esinevate tüve- ja sufiksiallomorfide normivastaste ühendite põhjal ei ole võimalik otsustada, kas tegemist on olnud reeglite abil moodustamise või olemasolevate allomorfide ühendamisega ehk teisisõnu, tüve moodustamise (stem formation) või tüve valikuga (stem selection) (Hokkanen 2001: 103-104). Selliseid olemasolevate tüve-ja sufiksiallomorfide normivastaseid ühendeid esineb ka keeleõppijate testivastuste hulgas:

\section{(3) talvirengaja, vieraja, vilkaja, nirkaja}

Kui õppijate lähtekeeleks on sihtkeelele tüpoloogiliselt lähedane, sarnase morfoloogiasüsteemiga sugulaskeel, ühendatakse käänamisel peale sihtkeele allomorfide sageli omavahel ka lähte- ja sihtkeele allomorfe:

\section{(4) vieraseja, vilkaseja, kangaseihin, patsasia}

Sellisel juhul ei ole selget piiri lähte- ja sihtkeele koodide vahetamise vahel, vaid lähte- ja sihtkeele koodid segunevad käänamisprotsessis (Riionheimo 2002: 201202). Lähte- ja sihtkeele koodide seostamine (code-blending) on morfoloogiline nähtus, mille puhul kahe keele morfeemid ühendatakse sama sõna sees, kusjuures lähtekeele fonoloogilised jooned püsivad muutumatuna (Kaufman, Aronoff 1991: 177, 1989: 202, Riionheimo 2002 järgi). Lähte- ja sihtkeele koodide seostamine peegeldab olukorda, kus kahe keele morfoloogiasüsteemid ei ole õppija keeletajus veel piisavalt eraldunud, vaid on enam või vähem kattuvad. Seetõttu segunevad moodustatavas vormis lähte- ja sihtkeele nii normipärased kui ka -vastased allomorfid. Tähelepanu väärib, et lähte- ja sihtkeele koodide segunemist ei esine üldse eesti edasijõudnud õppijate testivastustes. Algajate testivastustes seevastu seostuvad ulatuslikult nii normipärased kui ka normivastased lähtekeele tüve- ja sihtkeele sufiksiallomorfid. Selle põhjal võib järeldada, et edasijõudnud õppijad on juba läbinud lähte- ja sihtkeele morfoloogiasüsteemide kattumise etapi, algajate keeletajus aga on kahe keele süsteemid veel vähemalt osaliselt kattuvad.

Järsk piiritõmbamine reeglite abil käänamise ja allomorfide ühendamise vahele ei ole keeleõppe seisukohalt ehk vajalikki. Õppijad peavad vormi moodustamisel igal juhul valima tüve- ja sufiksiallomorfide kombinatsioonide hulgast sobiva sõltumata sellest, kas tüveallomorf on moodustatud reeglite rakendamise tulemusena või mälu põhjal. Valik eri kombinatsioonide vahel viitab aga juba analoogiaprotsessidele. Ka lähte- ja sihtkeele koodide seostamine on üleminekuvormiks reeglite ja analoogia vahel.

Analoogiat on käsitletud üldise lähenemisprintsiibina, metodoloogiana (nt Ehala 1996), aga ka keelte kontrastiivse uurimise ja võõrkeele õpetamise teoreetilise alusena (Eslon 2005). Analoogia põhineb sarnasusel. Esa Itkose (1992: 42) väitel "ei ole olemas mingit ühest kriteeriumi määratlemaks, kui väikest sarnasust võib veel nimetada analoogiaks." Eesti ja vene õppijate moodustamisprotsessis võib "sarnasuse jõud" (Paunonen 1983: 70) ilmneda mitmeti. Siiski on alati tegemist "struktuurilise", mitte "vaid täheldatava" sarnasusega, klassikalise proportsionaalse analoogiaga (Itkonen 1992: 41). Proportsionaalne analoogia on ainus mall, mille keeleõppijad spontaanselt ise loovad ja mis seetõttu on psühholoogiliselt usutavam kui mis tahes teine mall (Anttila 1989: 88-89, 105). Moodus- 
tatava sõna ja mallsõna vahelise sarnasuse aste sõltub sellest, millised tunnusjooned on õppija arvates sarnasuse aluseks ja kui palju neid tunnusjooni on.

Nii eesti kui ka vene õppijad toetuvad sõna käänamisel sageli sihtkeele tuttavamale sõnale. Mallsõna analoogia on õppijate hulgas levinud võte, eriti tehissõnade, aga ka "tavaliste" sõnade käänamisel. Analoogia võimaldab luua psühholoogiliselt motiveeritud seoseid koguni algselt kokkukuulumatute sõnade ning grammatiliste tunnuste vahel (Hint 1998: 234). Seetõttu vaheldub moodustatava sõna ja mallsõna vahelise sarnasuse aste õppijate keeletajus suuresti.

Omaette rühma kuuluvad sellised moodustatava sõna ja mallsõna paarid, mis on samasuguse fonoloogilise ehitusega. Sellisel juhul vahetatakse moodustatava sõna käänamisel vaid mallsõna algushäälikud. Kui mallsõna on valitud õigesti ja seda osatakse käänata, on tulemus normipärane:

(5) syhmiä nagu tyhmiä sulkkeihin nagu pankkeihin laineita nagu herneita

Samas võidakse paigutada näiteks $o$ - ja $u$-tüvelised testisõnad põhimõtteliselt täiesti õigesti samasse rühma, aga $o$-vokaal siirdub $u$-vokaali kohale ja juhib õppija valele teele:

(6) herkku : herk/koja : herkkuita ei herkkoja ikkagi, sest see meenutab mingil määral sõna kirkkoja. Samasugune sõna, selle järgi tegin. herkkuisiin : herk/kuista

(7) matkalaukku Esimene osa jääb samaks. laukku kõlab nagu herkkuja või herkku, ma panen siis kohe matkalaukkoja matkalauk-laukkoilauk- matka/lauk/kui- lauk- laukkoja laukkoisiin matkalaukkoilaukkui-matkalaukkoisiin matkalauk/koista matkalaukkoista

Kui õppija mäletab õpikust mõne sihtkeele sõna käänamist ja proovib seda kasutada võimalikult paljude testisõnade moodustamisel, piisab sarnasuse aluseks pelgalt silpide arvust:

(8) pankki : pankkoista nagu kissa: kissoista veuloista nagu kissoista musiikkiliikkoja nagu kissoja

Analoogia defineerimine loova protsessina, mis põhineb võrreldavate vormide tegelikul või oletataval sarnasusel, on nende näidete põhjal niisiis põhjendatud. Õppijad tõlgendavad sarnasust moodustatava sõna ja mallsõna vahel vägagi varieeruvalt, kuid kunagi ei ole see täiesti alusetu. Kõige sagedamini luuakse sarnasusseos moodustatava sõna ja mallsõna vahel siiski sõna lõpphääliku(te) alusel:

(9) pankki See on teistsugune kui herkku ja kirkko. pankkeja pankkeja pank/kei/ta ei pan- pankkei/siin pan-pankei- pan/koista või pan/ keista pankeista siiski.

Sõna lõpphäälik(ud) on õppija jaoks tähtsaim morfofonoloogiline vihje ka siis, kui testisõna tuleb paigutada käändtüüpi (paradigmasse). Sellisel juhul on tegemist eelnevast erineva analoogiavormiga. Analoogia, mida võiks nimetada paradigmaatiliseks, toimib reeglite rakendamise baasina ja seostab omal kombel reeg- 
lid ja paradigmad. Paradigmaatiline analoogia on üleminekuvorm reegli- ja analoogiapõhise moodustamise vahel (nagu ka lähte- ja sihtkeele koodide seostamine). Paradigmaatilist analoogiat esineb ainult vene õppijate käänamisprotsessis ja see on tõenäoliselt tingitud õpetamisviisist (intervjueerija - A.K., õpilane - V.):

(10)

А.К.: И как ты рассуждаешь, когда тебе надо образовать форму?

V.: Я смотрю на окончание, на основу, в какую группу принадлежит.

A.К.: И теперь, когда ты знаешь, какая это основа и какая группа, что ты делаешь дальше?

V.: Ну добавляю окончания.

Eesti õppijate käänamisprotsessis on lähtekeele analoogia eriti oluline, sellel on mitmeid esinemisvorme nagu sihtkeele analoogialgi. Ootuspäraselt kasutatakse lähtekeele analoogiat kõige enam eesti ja soome keeles samatüvelistes sama käänamismalliga sõnades:

(11) herne : hernest : herneid, herneita : hernei/ssa : hernei/sta

(12) toinen : toisia, see võiks nüüd olla selle järgi, et eesti keeles on teine ja teisi. Sisseütlev on toisiin ja seestütlev on toisista.

Näited $(11,12)$ osutavad, et eesti õppijate lähtekeele analoogia põhineb eeskätt paradigmade, mitte niivõrd üksiksõnade sarnasusel (Anttila 1989: 89). See ei ole üllatav, sest analoogiale on omane järgida n-ö paradigmaatilist reeglipära (Hint 1998: 242). Seevastu lähte- ja sihtkeele tüve erinevuse tõttu võib aga õppijal jääda märkamata lähte- ja sihtkeele käänamismallide sarnasus ja see suunab teda kasutama sihtkeele reegleid või tüve- ja sufiksiallomorfide ühendamist:

(13) hyinen : hyi/neis- Tähendust jälle ei tea. Osastav võiks olla kuidagi hyineja, sisseütlev hyi/niin. Jälle selle mitmuse osastava järgi, ainult teine lõpp. Ja seestütlev hyi/neista.

Lähtekeele analoogia ei ilmne alati tingimata õppija moodustatud vormi tasandil, vaid viitab pigem protsesside siirdumisele:

(14) tuode : tuot- tuoteja. Ega tuode ei ole ju toode? Eesti keele mitmuse osastav on tooteid. tuotteja : tuotteissa : tuotteista

(15) laine : laineja : laineista ei laineista : laineista. laineista, selle sõna puhul ma oletan, et see tähendab lainet ja siis ja siis laintest oleks eesti keele seestütlev. Ma teen siis seestütleva eesti keele järgi: laineista.

Vihjeid selles suunas, et sufiksite aglutineerimisprotsessi tajutakse eesti ja soome keeles sarnasusena sõltumata sellest, millised konkreetsed sufiksid tüvele liidetakse, esines juba eesti ja soome mitmusevormide psühholingvistilist sarnasust käsitlevas uurimuses (Kaivapalu 2004: 67-68). Küsimus ei ole niisiis ainult teatud tüvede ja sufiksite ülekandest lähtekeelest sihtkeelde, vaid lähtekeele moodustamismehhanismide siirdumisest sihtkeelde. Antud juhul sobib soome vokaaltüvelise $i$-mitmusliku käändevormi malliks eesti konsonanttüveline de-mitmuslik vorm. Sellises olukorras hakkab lähtekeele käänamismall sageli võistlema 
sihtkeele reeglitele tugineva moodustamismehhanismiga ja, nagu selgub näidetest $(16,17)$, võivad võitjaks osutuda mõlemad.

(16) kangas, see on eesti keelega sarnane. kangaita : kangastest : kangaikangista ei kangaista

(17) kangas, eestikeelne sõna kango- kangoia : kanga- kan/goi/sse : kangas kangaista kangoista

Viimati esitatud näites on lähtekeele mall aktiviseerunud seejärel, kui õppija on naasnud testi lähtevormi, ainsuse nominatiivi juurde. Vaatamata sellele on õppija otsustanud siiski rakendada sihtkeele reegleid, mis antud juhul viivad normivastase tulemuseni. Eesti õppijate kommentaarides ja intervjuudes esineb arvukaid näiteid sellest, kuidas õpitud reeglid takistavad lähtekeele käänamismalli kasutamist juhtudel, kus see ka sihtkeeles annaks normipärase tulemuse. Eriti algajad ei söanda sageli ära kasutada lähte- ja sihtkeele käänamismallide sarnasust. Edasijõudnud on lähtekeele analoogia rakendamisel tunduvalt julgemad: sellest annab tunnistust eesti ja soome keeles sama käänamismalliga sõnade suur õigete vastuste protsent nii kirjalikus ja suulises üksiksõnatestis kui ka jutustustes. Edasijõudnud õppijatel on seega analoogiapõhine vormimoodustus tunduvalt suurema kaaluga kui reeglitele toetuv moodustus.

Vene õpilastel toimib reeglipõhine moodustus edukalt siis, kui moodustatav sõna on tuttav ja käänamine lihtne, vt näiteid (18, 19; intervjueerija - A.K., ôpilased - P., K.):

(18)

A.К.: И как ты эти формы образуешь? Тебе же надо было очень быстро теперь сказать. Как ты склонял?

Р.: Иногда пытаюсь по правилам.

А.К.: Когда это иногда?

Р.: Когда лёгкие такие слова как школа, которых я знаю. Вот. A.К.: Те, которых ты знаешь, да.

P.: Те, которые я не знаю, те тогда сделаю по примеру.

A.К.: Ты можешь сказать, как ты образуешь форму? По правилам? К.: Ну да, иногда по правилам.

А.К.: А когда по правилам?

К.: Ну когда всё-таки слова, которые часто употребляются, такие, как koulu и такие, с самого начала знакомые. Но когда такие слова, которые я не знаю, только звучит знакомо, но значение не знаю совсем, тогда конечно, как кажется.

А.К.: Как кажется, да. Значит, знакомые слова по правилам, а незнакомые как чувствуется?

К.: Ну да.

Vene õppijad proovivad seega alguses käänata testisõnu reeglite abil. Kui see aga ei õnnestu unustamise, keerulise reegli või liiga lühikese aja tõttu, toimitakse "tunde" või "vaistu” järgi ehk sihtkeele analoogiale toetudes: 
А.К.: Как ты образуешь форму партитива?

N.: Но во-первых тут в основе одна гласная, значит с партитивом будет -ja, потому что koulua нельзя сказать, kouluja будет правильно. Вот тут kerros $-s$ на конце, которое меняется на $-k s i$, и добавляем окончание -a. kerroksia получается вот.

A.К.: Значит, ты образуешь эти формы по правилам ?

N.: Ну да, постараюсь.

А.К.: А если не получается? Если постараешься, но не получается, что ты тогда делаешь?

N.: Но не знаю, может быть по интуиции.

А.К.: По интуиции, да. Очень многие делают иногда по интуиции.

Если если эта правила работает, тогда по правилам, да?

N.: Ну да.

А.К.: И если не работает почему-то, тогда по интуиции?

N.: Да. Вот тут kangaita.

Analoogia terapeutiline ülesanne on siin samasugune kui keeleajaloos: ühtlustada, siluda ja korrastada süsteemi, kui piltlikult öeldes ei mahu keerulised hierarhilised reeglid enam õppija pähe ära (Hint 1998: 233-234). Kuna vene õppijate suulise üksiksõnatesti tulemused on peaaegu kõikide testisõnade osas paremad kui kirjaliku üksiksõnatesti tulemused, on põhjust oletada, et õpitud reeglid kalduvad takistama ka sihtkeele mallsõnale tuginevat analoogiapõhist vormimoodustust.

Nii eesti kui vene õpilaste reeglitel põhineva käänamise tõhusust vähendab asjaolu, et põhjalikult õpitud ja harjutatud reegleid sageli enam mõne aja pärast ei mäletata. Soome noomeni käänamine mitmuses näib eriti tüvevahelduste, aga ka sufiksivariatsiooni osas olevat piisavalt keeruline, et õppijal on hõlpsam jõuda parema tulemuseni analoogia abil. Siiski on igal käänamisstrateegial sihtkeele omandamise eri etappidel oma ülesanne ning strateegiavalik sõltub vähemalt osaliselt õppijate lähtekeelest (vt joonis 1).

\section{Eesti õppijad}

\begin{tabular}{cll} 
Reeglid Ühendamine & $\begin{array}{l}\text { Proportsionalne sihtkeele } \\
\text { analoogia (üksiksõnade sarnasusel } \\
\text { põhinev) }\end{array}$ \\
& $\begin{array}{l}\text { Lähte- ja sihtkeele } \\
\text { koodide seostamine }\end{array}$ & $\begin{array}{l}\text { Proportsionalne lähtekeele } \\
\text { analoogia (paradigmade sarnasusel } \\
\text { põhinev) }\end{array}$ \\
\hline Reeglid Ühendamine & $\begin{array}{l}\text { Paradigmaatiline } \\
\text { sihtkeele analoogia }\end{array}$ & $\begin{array}{l}\text { Proportsionalne sihtkeele } \\
\text { analoogia (sõnavormide } \\
\text { sarnasusel põhinev) }\end{array}$ \\
& Vene õppijad
\end{tabular}

Joonis 1. Eesti ja vene õppijate strateegiad soome mitmusevormide käänamisel

Nii eesti kui ka vene õppijad kasutavad niisiis soome noomenite käänamisel sõnavormide moodustamist reeglite abil, tüve- ja sufiksiallomorfide ühendamist 
ning mallsõna analoogiat. Ühesugusele, peamiselt reeglikesksele õpetamistraditsioonile vaatamata on eesti õpilased vene õpilastest märksa altimad toetuma nii lähte- kui ka sihtkeele analoogiale. Edasijõudnud eesti õpilased on jõudnud juba sellisesse sihtkeele omandamise etappi, et nende keeletajus lähte- ja sihtkeele morfoloogiasüsteemid enam ei segune. Seetõttu oskavad edasijõudnud käänamisel ära kasutada lähte- ja sihtkeele mallsõnu ning analoogial põhinev moodustamine on valdav. Paremaid tulemusi ei põhjusta seega analoogiline vormimoodustus kui selline, vaid arusaam, millal lähtekeele mallsõnast on abi ja millal see eksitab. Olgu märgitud, et kui sihtkeele analoogia põhineb eeskätt üksikute sõnavormide sarnasusel, siis lähtekeele analoogia aluseks on pigem paradigmade sarnasus. Eesti algajad kasutavad edasijõudnutega võrreldes lisaks ulatuslikule lähte- ja sihtkeele analoogiale rohkem reegleid. Käänamine tugineb reeglitele seega eelkõige õpingute algetapil. Reeglipõhist vormimoodustust kasutatakse lihtsama käänamisviisiga sõnades, mille lõpphäälikud annavad õppijale selge vihje sõna paradigmaatilisest kuuluvusest. Erinevalt edasijõudnud eesti õppijatest seostavad algajad sama sõnavormi sees ka lähte- ja sihtkeele allomorfe.

Vene õppijad seevastu lähtuvad käänamisel eelkõige reeglitest ning sihtkeele mallsõna analoogia võetakse appi alles siis, kui reeglite rakendamine mingil põhjusel ei õnnestu. Huvitava üleminekuvormina reeglite ja analoogia vahel esineb vene õppijatel paradigmaatiline sihtkeele analoogia: testisõna paigutatakse (peamiselt lõpphäälikute) analoogia alusel teatud käändtüüpi (paradigmasse) ja seejärel hakatakse sõna käänama selle käändtüübi reeglite alusel.

Lähtekeelel on niisiis oma osa õppijate käänamisstrateegia valikus. Soome keelest veel ulatuslikumalt tüvevaheldusi kasutav eesti keel lähtekeelena loob soodsa pinnase toetuda käändevormide moodustamisel analoogiale. Nii lähtekui ka sihtkeele analoogia osutus eesti õppijate jaoks käänamisel palju olulisemaks kui senise valdavalt reeglikeskse õpetamistraditsiooni põhjal võinuks oletada. Vene õppijate puhul otsustas käänamisstrateegia valiku esmajoones testisõna käänamise keerukus ning tuttavus. Samuti sõltus reeglite ja analoogia vaheline tööjaotus nii eesti kui vene õppijate puhul sihtkeele oskuse tasemest. Seda on põhjust senisest enam arvestada ka keeleõppes.

\section{Käänamisstrateegiad ja keeleõpe}

Eesti koolide soome keele õpetuses on sageli arutletud selle üle, kus, millisel määral ja kuidas ära kasutada lähte- ja sihtkeele lähisugulusest tulenevat tüpoloogilist ja leksikaalset sarnasust. Eesti õppijate suhtumine soome keele õppimisse on eriti õpingute algperioodil liigagi pealiskaudne ja põhineb eksiarvamusel, et soome keeles ei ole eestlasele midagi rasket (Kelmsaar 1995: 36). Peamiselt sellisest suhtumisest tuleneb asjaolu, et õpetajad on sunnitud pidevalt rõhutama keeltevahelisi erinevusi ning sarnasused jäävad tagaplaanile. Õpilaste endi esimesed õppimiskogemusedki veenavad, et lähtekeele mallist ei ole sugugi alati abi. See suurendab õppija ebakindlust veelgi. Osaliselt seetõttu ei söanda (ega õppimise algperioodil ka oska) õppijad veel kasutada lähtekeele analoogiat seal, kus see sihtkeeleski viiks normipärase tulemuseni. Alles hiljem, kui lähte- ja sihtkeele morfoloogiasüsteemid on õppijate keeletajus juba piisavalt teineteisest 
eraldunud, pääseb lähtekeele mall vabalt toimima ning lähtekeele mõju sihtkeelele on valdavalt positiivne.

Õppijad vajavad niisiis senisest enam teadmisi sellest, millal lähtekeele käänamismalli kasutamine sihtkeele vormimoodustuses on põhjendatud ja millal mitte, ehk teisisõnu, millal lähtekeele mõju on positiivne ja millal negatiivne. Oleks hea, kui õppijaid suunataks laiemaltki võrdlema lähte- ja sihtkeele süsteeme (Latomaa 1993: 10, Martin 1996: 116, Pälli, Latomaa 1997: 28, Dufva, Isoherranen 1997: 164). Õppijate arusaamisel lähte- ja sihtkeele nähtuste sarnasusest ja erinevusest on sageli otsustavam tähendus kui keelte tüpoloogilisel sarnasusel ja erinevusel. Keeleteadlikkuse ja sõnamuutmisstrateegiate tundmine aitab üldisemaski plaanis paremale keeleoskusele kaasa.

Lisaks teadmistele lähte- ja sihtkeele erinevuste ning sarnasuste kohta vajavad õpetamisel enam tugevdamist ka sõnavormide vahelised ehk paradigmasisesed seosed. Varasemad uurimused (Paunonen 1983: 61, Martin jt 2001: 74-75) on osutanud, et paradigma on selge käändevorme ühendav tegur emakeelse soome keele kõneleja keeletajus. Käesoleva uurimuse erinevat tüüpi testiülesannete põhjal võib tõdeda sama soome keele õppijate kohta. Sama tüveallomorfi süsteemipärane esinemine eri käändevormide moodustamisel nii üksiksõnatestis kui ka jutustustes annab tunnistust sellest, et õppijate keeletajus on sõna käändevormid seostunud paradigmadeks või skeemideks. Testis üldse mitte esinevate käändevormide kasutamine abivahendina suulises üksiksõnatestis, näiteks mitmuse illatiivi moodustamine ainsuse illatiivi abil, toetab antud seisukohta veelgi. Olgu märgitud, et paradigmasisese seosevõrgustiku tajumise osas on õppijate vahel suuri erinevusi. Sihtkeele paradigmasisesed seosed ei tarvitse õppija keeletajus olla sugugi lõplikult kinnistunud ega kõiki käändevorme hõlmavad. Õppijate paradigmad võivad jääda ebatäielikuks ja lünklikuks pikaks ajaks ning analoogia laialdasem kasutus aitaks õppijaparadigmasid järk-järgult lähendada sihtkeele paradigmadele.

Võõrkeeleõppele on omane analoogia ulatuslik rakendamine üldise printsiibina ning konkreetsetel juhtudel nii moodustatud vormi kui ka protsessi tasandil. Lähedase sugulaskeele kiirema õppimise üks põhjus ongi tõenäoliselt asjaolu, et tüpoloogiliselt sarnaste keelte puhul annab lähtekeele analoogia rakendamine sihtkeeleski soovitud tulemuse sagedamini kui tüpoloogiliselt kaugemate keelte puhul.

\section{Kirjandus}

Anttila, Raimo 1989. Historical and Comparative Linguistics. Second Revised Edition. Amsterdam/Philadelphia: Benjamins

Bates, Elizabeth; MacWhinney, Brian 1987. The competition, variation and language learning. - Mechanisms of Language Acquisition. Ed. by Brian MacWhinney. Hillsdale, New Jersey: Lawrence Erlbaum Associates, 157-193.

Block, E. L. 1992. See how they read: Comprehension monitoring of L1 and L2 readers. TESOL Quarterly 26 (2), 319-343.

Bybee, Joan 1988. Morphology as lexical organisation. - Theoretical Morphology. Ed. by M. Hammond, M.Noonan. San Diego: Academic Press, 119-141.

Bybee, Joan 2001. Phonology and Language Use. Cambridge Studies in Linguistics 94. New York: Cambridge University Press. 
Dufva, Hannele; Isoherranen, Sari 1997. Kääntyvätkö ajatukset vieraalle kielelle? Käsityksiä vieraan kielen käytöstä. - Translation - Acquisition - Use. AFinLA:n vuosikirja 1997. Toim Anne Mauranen, Timo Puurtinen. Suomen soveltavan kielitieteen yhdistyksen julkaisuja 55. Jyväskylä, 161-173.

Ehala, Martin 1996. Integreeritud keeleteooria võimalikkusest tänapäeva keeleteduses (II). - Keel ja Kirjandus 6, 375-384.

Eslon, Pille 2005. Значение аналогии для лингвистики. - Eesti Rakenduslingvistika Ühingu aastaraamat 1 (2004). Koost Margit Langemets, toim Maria-Maren Sepper. Tallinn: Eesti Keele Sihtasutus, 35-51.

Hint, Mati 1998. Häälikutest sõnadeni. Eesti keele häälikusüsteem üldkeeleteaduslikul taustal. Teine, ümbertöötatud trükk. Tallinn.

Hockett, Charles F. 1954. Two models of grammatical description. - Word 10/2-3, 210234.

Hokkanen, Tapio 2001. Slips of the tongue. Errors, repairs, and a model. Studia Fennica Linguistica 10. Finnish Literature Society. Helsinki.

Itkonen, Esa 1992. Analogian käsite ja sen rooli kognitiivisessa kielitieteessä. - Kielitieteellisen kentän kartoitusta. Toim Esa Itkonen, Anneli Pajunen, Timo Haukioja. Turun yliopiston suomen kielen ja yleisen kielitieteen laitoksen julkaisuja 39. Turun yliopisto, 39-40.

Itkonen, Terho 1976. Syntaktisten vaikutusyhteyksien luonteesta. - Virittäjä 80, 52-81.

Jaakkola, Hanna 1997. Kielitieto kielitaitoon pyrittäessä. Vieraiden kielten opettajien käsityksiä kieliopin oppimisesta ja opettamisesta. Jyväskylä Studies in Education, Psychology and Social Research 128. Jyväskylän yliopisto. Jyväskylä.

Jarvis, Scott; Odlin, Terrence 2000. Morphological type, spatial reference, and language transfer. - SSLA 22, 535-556.

Järvikivi, Juhani 2003. Allomorphy and Morphological Salience in the Mental Lexicon. Publications in the Humanities 32. University of Joensuu. Joensuu.

Kaivapalu, Annekatrin. 2004. Kui sarnane on sarnane? Eesti ja soome mitmusevormide psühholingvistilisest reaalsusest. - VIRSU II. Suomi ja viro kohdekielinä. Toim Helena Sulkala, Heli Laanekask. Oulun yliopiston suomen ja saamen kielen ja logopedian laitoksen julkaisuja 24. Oulu, 62-71.

Kaivapalu, Annekatrin 2005. Lähdekieli kielenoppimisen apuna. Jyväskylä Studies in Humanities 44. Jyväskylän yliopisto.

Kaivapalu, Annekatrin 2006. Kontrastiivlingvistika ja võõrkeele õppimine. - Eesti-soome kontrastiivseminar Männikul 8.-9.05.2004. Lähivertailuja 16. (Ilmumas.)

Kasik, Reet 1999. Johdatus viron kielen tutkimukseen. Castrenianumin toimitteita 55. Helsinki.

Kelmsaar, Vallo 1995. Suomenkielisen asiatekstin toimittamisesta (erehdyksiä virolaisten kirjoittamissa suomenkielisissa teksteissa). Tallinna Pedagoogikaülikool. Lopputyö.

Latomaa, Sirkku 1993. Mitä hyötyä on oppijoiden kielitaustan tuntemisesta? Kohdekielena suomi. Näkökulmia opetukseen. Toim Eija Aalto, Minna Suni. Korkeakoulujen kielikeskuksen selosteita 1. Jyväskylän yliopisto. Jyväskylä, 9-31.

Lipasti, Järvi 2005. Suomen kielen opettajien täydennyskoulutus Virossa. - Esitelmä VIRSU-seminaarissa 1.4.2005 Jyväskylässä.

MacWhinney, Brian 1987. The Competition Model. - Mechanisms of Language Acquisition. The 20th Annual Carnegie Symposium on Cognition. Ed. by Brian MacWhinney. New Jersey: Erlbaum, 249-308.

Martin, Maisa 1995. The Map and the Rope. Finnish Nominal Inflection as a Learning Target. Studia Philologica Jyväskyläensia 38. University of Jyväskylä. Jyväskylä.

Martin, Maisa 1996. Morphological production and descriptions of Finnish. - Approaches to Second Language Acquisition. Ed. by Kari Sajavaara, Courtney Fairweather. Jyväskylä Cross-language Studies. University of Jyväskylä, 187-193. 
Martin, Maisa 2006. Suomi ja viro oppijan mielessä. Näkökulmia taivutusmuotojen prosessointiin. - VIRSU-seminaari Jyväskylässä 1.4.2005. Lähivertailuja 17. (Ilmumas.)

Martin, Maisa; Hihnala, Riikka; Sivonen, Ulla 2001. Leksikko mielessä. Pieni koe sanojen järjestymisestä mentaalisessa leksikossa. - Tietotyön yhteiskunta - kielen valtakunta. AFinLA:n vuosikirja 2001. Toim Mirjaliisa Charles, Pirjo Hiidenmaa. Suomen soveltavan kielitieteen yhdistyksen (AFinLA) julkaisuja 59. Jyväskylä, 61-80.

Milovidova, Olga 1999a. Pietarin koulu-lyseo 204. - Perspektiivejä - kulttuuri, kieli ja koulutus. Toim Sirkka Laihiala-Kankainen, I. P. Lysakova, S. A. Rasčetina. Soveltavan kielentutkimuksen keskus. Jyväskylän yliopisto, 73-77.

Milovidova, Olga 1999b. Kulttuurienvälinen lähestymistapa koulun opetussuunnitelman laatimiseen. - Perspektiivejä - kulttuuri, kieli ja koulutus. Toim Sirkka LaihialaKankainen, I. P. Lysakova, S. A. Rasčetina. Soveltavan kielentutkimuksen keskus. Jyväskylän yliopisto, 292-293.

Milovidova, Olga 1999c. Mitä suomea opetetaan Pietarissa. - Yhdeksän tutkielmaa suomesta toisena ja vieraana kielenä. Toim Maisa Martin, Kaarlo Voionmaa. Jyväskylän yliopiston suomen kielen laitoksen julkaisuja 40. Jyväskylä, 61-79.

Muuk, Elmar 1925. Häälikuseaduslikkus ja analoogilisus meie õigekeelsusnähtuste hindamismõõdupuuna. - Erelt, Tiiu 2002. Eesti keelekorraldus. II osa. Lugemik. Tallinn: Eesti Keele Sihtasutus, 343-360.

Mäntylä, Taimi 1993. Aloitamme yhdessä. Soome keele õpik lastele I. Tallinn: Valgus. Mäntylä, Taimi 1994. Jatkamme yhdessä. Soome keele õpik lastele II. Tallinn: Valgus. Mäntylä, Taimi 1996. Juhlimme yhdessä. Soome keele õpik lastele III. Tallinn: Valgus.

Niemi, Jussi; Laine, Matti; Tuominen, Juha 1994. Cognitive Morphology in Finnish: Foundations of a New Model. - Language and Cognitive Processes 9, 423-446.

Niemi, Jussi; Heikkinen, Janne; Järvikivi, Juhani 2001. Miksei kania vaikka munoja? XXVII kielitieteen päivät Oulussa 19.-20.5.2000. Toim Helena Sulkala, Leena Nissilä. Acta Universitatis Ouluensis B Humaniora 41. Oulun yliopisto. Oulu, 191-197.

Odlin, Terrence 1989. Language Transfer. Cross-linguistic Influence in Language Learning. Cambridge, USA: Cambridge University Press.

Parviainen, Aira; Sander, Klarika 1998. Löytöretki Suomeen. Helsinki: Finn Lectura.

Paunonen, Heikki 1983. Allomorfien dynamiikkaa. - Nykysuomen rakenne ja kehitys. Näkökulmia kielen rakenteisiin 1. Toim Auli Hakulinen, Pentti Leino. SKS, 57-85.

Pälli, Pekka; Latomaa, Sirkku 1997. Aikuisten maahanmuuttajien suomen kielen taito. Helsinki: Opetushallitus.

Remes, Hannu 1995. Suomen ja viron vertailevaa taivutustypologiaa. Oulun yliopiston suomen ja saamen kielen ja logopedian laitoksen julkaisuja 2. Oulu.

Riionheimo, Helka 2002. How to borrow a bound morpheme? Evaluating the status of structural interference in a contact between closely-related languages. - SKY Journal of Linguistics 15 (2002), 119-143.

Ringbom, Håkan 1987. The Role of the First Language in Foreign Language Learning. Clevedon: Multilingual Matters LTD.

Sajavaara, Kari 1994. Äidinkieli vieraan kielen käyttämisen perustana. - Kieli on, sopii sanoa. Toim Vuokko Eskola, Tuire Lukkarinen. ÄOL:n vuosikirja XL. Helsinki, 19-28.

Sajavaara, Kari 1999a. Toisen kielen oppiminen. - Kielenoppimisen kysymyksiä. Toim Kari Sajavaara, Arja Piirainen-Marsh. Soveltavan kielentutkimuksen keskus. Jyväskylän yliopisto. Jyväskylä, 73-102.

Sajavaara, Kari 1999b. Kontrastiivinen kielentutkimus ja virheanalyysi. - Kielenoppimisen kysymyksiä. Toim Kari Sajavaara, Arja Piirainen-Marsh. Soveltavan kielentutkimuksen keskus. Jyväskylän yliopisto. Jyväskylä, 103-128. 
Sark, Kaare 1994. Yy kaa koo. Suomea kouluille 1. Tallinn: ESKO Koolitus.

Sark, Kaare 1995. Yy kaa koo. Suomea kouluille 2. Tallinn: ESKO Koolitus.

Schmidt, Richard 2001. Theories, evidence, and practice in foreign language teaching. Conference on Nordic Languages as second and foreign languages. Reikjavík, May, 2001.

Swain, Merrill; Lapkin, Sharon 1995. Problems in output and the cognitive processes they generate: A step toward second language learning. - Applied Linguistics 16 (3), $371-391$.

\section{Kaudviited}

Hankamer, Jorge 1992. Morphological parsing and the lexicon. - Lexical Representation and Process. Ed. by W. Marslen-Wilson. Cambridge, USA: The MIT Press, 392-408.

Kaufman, D.; Aronoff, Mark 1989. Morphological interaction between L1 and L2 in language attrition. - Variation in Second Language Acquisition. Volume II: Psycholingvistic Issues. Ed. by Susan. Gass, Carolyn Madden, Dennis Preston, Larry Selinker. Multilingual Matters 50. Clevedon, Philadelphia: Multilingual Matters Ltd., 202-215.

Schade, Ulrich; Laubenstein, Uwe 1993. Repairs in Connectionist Language-Production Models. - Contributions to Quantitative Linguistics. Ed. by R. Köhler, B. Rieger. Dordrecht: Kluwer, 79-90.

\section{LISA 1. Käänamistest}

1. Moodusta järgmistest sõnadest mitmuse osastav, sisseütlev ja seestütlev kääne ning kirjuta sõna tähendus eesti keeles.

Образуй из следующих слов падежи monikon partitiuvi (keitä?mitä?), monikon illatïvi (keihin?mihin?), monikon inessïvi (keissä?missä?). Напиши значение слов по-русски.

\begin{tabular}{|l|l|l|l|l|}
\hline & mitm os & mitm sisseütlev & mitm seestütlev & tähendus \\
\hline & mon. partitiivi & mon. illatiivi & mon. inessiivi & значение \\
\hline koulu & & & & \\
\hline kerros & & & & \\
\hline veule & & & & \\
\hline lelu & & & & \\
\hline toinen & & & & \\
\hline kirkko & & & & \\
\hline nirkas & & & & \\
\hline kohde & & & & \\
\hline talvirengas & & & & \\
\hline laine & & & & \\
\hline sulkki & & & & \\
\hline kangas & & & & \\
\hline musiikkiliike & & & & \\
\hline opas & & & & \\
\hline
\end{tabular}




\begin{tabular}{|l|l|l|l|l|}
\hline kirje & & & & \\
\hline veistos & & & & \\
\hline hyinen & & & & \\
\hline hidas & & & & \\
\hline ohje & & & & \\
\hline patsas & & & & \\
\hline syhmä & & & & \\
\hline lakki & & & & \\
\hline herne & & & & \\
\hline kauppakeskus & & & & \\
\hline herkku & & & & \\
\hline pankki & & & & \\
\hline vilkas & & & & \\
\hline tuote & & & & \\
\hline matkalaukku & & & & \\
\hline vieras & & & \\
\hline
\end{tabular}

2. Kirjuta jutustus linnaekskursioonist. Jutusta mina- või meie-vormis või mõtle tegelased ise välja. Kasuta kõiki alljärgnevaid nimi- ja omadussõnu nii, et need vastaksid kindlasti tegusõna järel olevale küsimusele ning oleksid mitmuses. Võid lisada teisi vajalikke sõnu. Oluline on, et jutustus oleks terviklik ja selle keel võimalikult mitmekesine. Kui jutustus on valmis, kontrolli, kas kasutasid kõiki antud sõnu. Alusta nii:

Se tapahtui päivänä, jolloin kaikki näkyi kaksinkertaisena

Напиши рассказ о городской экскурсии. Расскажи от первого лица единственноого или множественного числа (я, мы) Можешь сама выдумать действующее лицо. Используй все нижеследующие имена существительные и прилагательные так чтобы они соответствовали управлению глагола и были бы во множественном числе. Ты можешь добавить и другие нужные для тебя слова. Важно чтобы рассказ был связной и его язык разнообразный. Написав рассказ, проверь использованы ли тобой все данные слова. Рассказ начни так:

Se tapahtui päivänä, jolloin kaikki näkyi kaksinkertaisena

1. Kes mida või keda imetles, vaatas, ostis, saatis, kohtas, andis?

Tegusõnad

ihailla mitä?

katsella mitä?

ostaa mitä?

lähettää mitä?

tavata ketä?

antaa mitä? 


\section{Nimisõnad}

kohde, kirkko, veistos, patsas, laine, koulu, kauppakeskus, kerros, pankki, musiikkiliike, herkku, herne, lelu, matkalaukku, kangas, lakki, talvirengas, tuote, kirje, opas, ohje

Omadussõnad

hidas, vieras, vilkas, toinen

2. Kes millest vaimustus, tüdines, kes millega tutvus, kes kuhu tuli?

Tegusõnad

ihastua mihin?

kyllästyä mihin?

tutustua mihin?

tulla mihin?

\section{Nimisõnad}

veistos, patsas, kirkko, kauppakeskus, pankki, ohje, kohde, koulu, kerros, musiikkiliike

Omadussõnad

vieras, toinen, hidas

3. Kes millest huvitatud oli või ei olnud, kellele mis meeldis või ei meeldinud, kes kust tuli?

Tegusõnad

olla kiinnostunut mistä?

pitää mistä? kenestä?

tulla mistä?

Nimisõnad

lelu, matkalaukku, talvirengas, tuote, opas, kirje, herkku, herne, kangas, lakki, laine

Omadussõnad

vilkas, hyinen 


\section{RULES AND ANALOGY IN FOREIGN \\ LANGUAGE LEARNING: \\ FINNISH PLURAL FORMS AS AN EXAMPLE}

\section{Annekatrin Kaivapalu}

This article deals with the processing strategies of Estonian and Russian learners inflecting some plural forms of Finnish nouns. The analysis is based on written and oral tests of context-free words and on the use of the same words in written narratives. The second data-type consists of the comments of the learners on their processing, and interviews with the learners. Both data types were used to determine the functions and efficiency of two central processing strategies, rules and analogy. The aim of the study was to explore whether, how and to what extent the source language and the level of target language skills influence the choice of processing strategy.

The study concludes that both the Estonian and the Russian learners produce the plural forms of the test words by applying rules, by combining stem allomorphs and inflectional allomorphs, and by analogy with the familiar target language words. The use of rules is more efficient in a situation when there are no exceptions and the inflectional process is algorithmically easy to describe. Where the inflectional process is complex, non-linear and hierarchical, analogy with the target language leads to better results.

However, the distribution and functions of the main inflectional strategies used by Estonian and Russian learners are different. Due to the similarity of the morphological systems of two closely related languages, Estonian and Finnish, the Estonian learners produce plural forms of Finnish both by analogy with the target language and by analogy with the source language. It is important to emphasize that while the analogy with the source language is based mainly on the similarity of word forms, the analogy with the target language tends to be based on the similarity of paradigms. The beginner level Finnish learners of Estonian origin also blend the codes of the source and the target languages by combining stem and inflectional allomorphs of both languages within the same word. Thus the inflectional systems of the two closely related languages are not yet separated in the minds of the beginners of the Estonian origin to the same extent as they are in the minds of the advanced Finnish learners of the Estonian origin.

The learners of teh Russian origin begin their inflectional process at first by applying the rules and they use analogy only if the processing by rules does not succeed. An interesting transitional variant between the rules and the analogy is the so-called paradigmatic analogy: learners place words analogically into morphological type (paradigm) according to the final sounds of the word and then inflect them by the rules for the type.

Consequently, it appears that the choice of the processing strategy depends, at least partly, on the source language and the level of the target language skills of the learners. 
Keywords: non-native language acquisition, Estonian and Russian learners, language testing, morphological skills, inflectional strategies, crosslinguistic influence, Finnish

Annekatrin Kaivapalu (1963) on lõpetanud Tallinna Pedagoogilise Instituudi eesti keele ja kirjanduse erialal. Kaitses magistrikraadi Tallinna Pedagoogikaülikoolis 1999. aastal, doktorikraadi Jyväskylä ülikoolis 2005. aastal. On töötanud Tallinna Pedagoogilises Instituudis, Eesti Keele Instituudis ja Kärdla Ühisgümnaasiumis. Alates 2003. aastast töötab Jyväskylä Ülikooli keelte õppetooli teadurina. On uurinud kõrvutavalt eesti ja soome muutemorfoloogiat, eesti ja soome üliõpilaste arvamusi emakeelest, lähtekeele mõju sihtkeele morfoloogia omandamisele, absoluutset ja suhtelist morfoloogilist komplekssust.

annek@dako.edu.ee

kaivapa@campus.jyu.fi 